\title{
CONSTRAINTS ON THE CAUSATIVE DERIVATION IN EARLY VEDIC: EVIDENCE FOR A DIACHRONIC TYPOLOGY OF TRANSITIVITY
}

\author{
LEONID KULIKOV \\ Ghent University \\ Leonid.Kulikov@UGent.be
}

\begin{abstract}
The present paper demonstrates the relevance of the semantic approach to transitivity (going back to Hopper and Thompson 1980) for the analysis of Vedic causative verbs. I will argue that in terms of this approach it is possible to explain a number of constraints on causative derivation (which cannot be explained in terms of the traditional, syntactic, definition) and to offer a unified account of the semantics of these verbs. I will also briefly discuss some theoretical implications of this analysis of causative verbs in Vedic for a diachronic typology of transitivity.
\end{abstract}

KEYWORDS: Causative; diachrony; transitivity; typology; Vedic.

\section{Semantic approach to transitivity: Preliminary remarks*}

During the last two decades of the 20th century, a number of studies on the typology of transitivity have appeared, such as, first of all, the seminal article by Hopper and Thompson (1980), "Transitivity in grammar and discourse"; see also, among others, Tsunoda (1981, 1985), and, more recently, Kittilä (2002). The pioneer study by Hopper and Thompson established important

\footnotetext{
* I would like to take this opportunity to express my thanks to the audience of the workshop (Arbeitstagung) "Struktur und Semantik der Verbalphrase" (Universität Jena, April 2006), where parts of this paper were discussed - in particular to Dag Haug, Heinrich Hettrich and Rosemarie Lühr, for suggestions and critical remarks. I would like to thank Eystein Dahl, Daniel Kölligan, Alexander Lubotsky, Robert Ryan, Krzysztof Stroński and Carlotta Viti for their criticism and valuable comments on earlier drafts of the paper. I gratefully acknowledge grant 275-70-009 (VENI-project) received from the Netherlands Organization for Scientific Research (NWO) and financial support from the Alexander von Humboldt-Stiftung.
} 
links between transitivity and certain semantic features. Transitivity is regarded as a complex set of parameters that are all concerned with the effectiveness with which an action takes place. These include the agentivity of the subject, referentiality and degree of affectedness of the object, telicity of the verb, and some others. The borderline between transitive and intransitive verbs cannot be drawn with accuracy in some cases, and semantic parameters can help to determine the boundaries between linguistically relevant syntactic classes of verbs.

In what follows I will demonstrate the relevance of this approach to transitivity for the analysis of the causative derivation in Vedic. This study is based on evidence from the Vedic corpus, including early post-Vedic texts (Sūtras and Smrtis), with special attention paid to the early Vedic language as attested in the most ancient Vedic text, the Rgveda (RV), that can approximately be dated to the second half of the second millennium BC. In Section 2, I will summarize the main morphological rules of the causative derivation in Vedic. Section 3 outlines the main constraints on causative derivation (traditionally formulated in terms of transitivity of the base verbs). Section 4 concentrates on the Vedic verbal forms that, in spite of their causative morphology, attest non-causative semantics. These seeming exceptions will be explained in Section 5 in terms of the revised definition of transitivity. Section 6 will briefly summarize the main theoretical implications of this analysis of causative verbs in Vedic for a diachronic typology of transitivity.

\section{Causative derivation in Vedic}

To begin with, it will be in order to outline the main morphological rules of the derivation of causative verbs in Vedic. The three major morphological devices relevant for the causative derivation include: (i) suffixation, as in causative presents, such as pat 'fly' : pāt-áya-ti; (ii) reduplication of the initial part of the root, as in causative aorists, cf. jan 'be born, generate, beget' : á-ji-janat 'has generated'; and (iii) root vowel alternation, traditionally described in terms of three ablaut grades, zero, full and lengthened, cf. pat 'fly' : pātáyati.

\subsection{Causatives in the present system}

In the present system, the most productive formation associated with the causative function is the -áya-causative. The choice of the full (guna) or long 
(vrddhi) root vowel grade is determined by the following simple rule: the root syllable should be long. That is, the lengthened grade mostly appears in the roots of the structure $\mathrm{CaC}$, while the full grade (guna) is selected by the roots of other structures. In other words, the suffix -áya-is attached to the root (i) in the full grade (o,e, ar, etc.) if the root syllable is long in the full grade (cf. budh 'to awaken' - bodháyati 'makes awaken'; cit 'perceive' - cetáyati 'makes perceive'; vrt 'turn' - vartáyati 'makes turn'); or (ii) in the lengthened grade $(\bar{a})$ if the root syllable is short in the full grade, i.e. contains $a$ before a single consonant (cf. pat 'fly' : pātáyati 'makes fly', naś 'perish, be lost' : nāśáyati 'destroys').

Historically, this morphological type can be uniformly explained as being based on the Proto-Indo-European ${ }^{*} o$-grade of the root, which yields $\bar{a}$ in open syllables in accordance with Brugmann's law (see e.g. Volkart 1994; and Lubotsky 1997), i.e. pātáya- < PIE *pot-éie-; cetáya- < PIE *k"oint-éie- (see LIV 382).

The -áya-causatives are opposed to another present formation with the suffix -áya- which has no causative meaning; cf. patáyati 'flies (about), flutters', cit : citáyati 'appears'. The formal difference between these two morphological types consists in the alternation grade of the root syllable. The first (causative) type shows lengthened or full grade, while the second type has full grade (in $\mathrm{CaC}$ roots, cf. pat : patáyati) or zero grade (in roots of other structures, cf. cit : citáyati). In other words, in contrast to the causative type, -áya-presents of this class have a short root syllable: $C a C$-áya-, $C \underset{a}{ } C$-áya(where $\boldsymbol{R}$ stands for the vocalic variant of a sonant).

The semantic distinction between the full/lengthened grade -áyaformations (= long root syllable -áya-formations) and the zero/full grade -áya-formations (= short root syllable -áya-formations) is well-known and noticed in all standard Indo-European and Vedic grammars. The former type (pātáyati) mostly includes causatives (e.g. pātáyati 'makes fall, makes fly', cetáyati 'makes appear, makes perceive'), while the class of the short root syllable -áya-formations (type patáyati) mainly consists of non-causative and, most often, intransitive presents; for the latter type, see Kulikov (2008).

Note that the formal opposition between these two morphological types can be neutralized in the case of (i) non-alternating (non-ablauting) verbal roots, which have the same root grade (for instance, zero grade - typically, $\bar{l}$ or $\bar{u}$ ) in all formations (cf. vìd 'be firm' : vìdáyati [not *vedáyati] 'makes firm'; ìkṣ 'look' : ìkśáyati 'makes look' (not *ekṣáyati) and (ii) some $\mathrm{CaC}$ roots (mostly those terminating in a nasal sonant, $m$ or $n$ ) which fail to lengthen the root syllable, cf. jan 'be born; beget' : janáyati 'begets, generates' [not 
*jānayati]. For some verbs, both short and long root syllable variants are attested in causatives, cf. gam 'go' - gamáyati/gāmáyati 'makes go, sends', śru 'hear' : śraváyati/śrāváyati 'makes heard; makes hear' (see Jamison 1983: 175f.). Thus, in formal terms, the -áya-presents derived from roots such as vìd and jan are ambiguous as far as the causative/non-causative opposition is concerned (see, in particular, Macdonell 1910: 393ff.; Renou 1952: 299).

\subsection{Causatives in the aorist system}

In the aorist system, causatives are mainly associated with reduplicated aorists. ${ }^{1}$ The reduplication syllable (with the reduplication vowel $u$ for $u$ roots and $i$ for other roots) is attached to the root in zero grade. The quantity of the reduplication vowel is determined in the same way as the root grade in -áya-causatives (see Jamison 1983: 217f.): the reduplication syllable should be long, thus the reduplication vowel $(i / u)$ is lengthened if the reduplication syllable is open (= followed by a single consonant) and therefore short; cf. dyut 'shine, be bright' - á-di-dyut-at 'has made bright'; jan 'be born' $a$-jī-jan-at 'has generated' (see Kulikov 2005 for details).

3. Verbal classes and constraints on the causative derivation in Vedic

Although both of the above-mentioned verbal formations, long root syllable -áya-presents and reduplicated aorists, are typically causative as opposed to the present and aorist formations of other types belonging to the same individual verbal system (IVS), there are a number of important exceptions to this regularity.

\subsection{Thieme's rule}

The most important exception was first formulated by Paul Thieme in his seminal book Plusquamperfektum im Veda (1929). It will hereafter be referred to as Thieme's rule. According to this rule,

(R1) Only intransitive verbs may have causative counterparts.

\footnotetext{
${ }^{1}$ For the origins of this formation, see, above all, Leumann (1962).
} 
In accordance with (R1), the -áya-presents and reduplicated aorists derived from transitive verbs do not causativize the underlying verb. Transitive verbs are defined, quite traditionally, though with some simplifications, as verbs which are constructed with accusative direct objects (for a detailed discussion of the criteria of objecthood and transitivity in Vedic, see Kulikov 2012). Thus, vardháyati 'makes increase; makes strong' is causative only as opposed to the intransitive middle present várdhate 'grows, increases' (cf. (3)), but synonymous with the transitive active present várdhati 'makes grow, increase, makes strong' (see, for instance, Gotō 1987: 290). ${ }^{2}$ Both formations are thus used identically, as illustrated in (1-2):

(1) (RV 7.77.6ab)

$\begin{array}{llll}\text { yâ̆m } & \text { tvā } & \text { divo } & \text { duhitar } \\ \text { who:ACC.SG.F } & \text { you:ACC } & \text { Heaven:GEN.SG } & \text { daughter:VOC.SG } \\ \text { vardh-áya-nti } & \quad \text { úșahạ } & \text { su-jāte } \\ \text { grow-PR.CAUS-3PL.ACT } & \text { Ușas:VOC.SG } & \text { well-born:VOC.SG.F } \\ \text { matíbhir } & \text { vásișthāḥ } & \\ \text { prayer:INS.PL } & \text { Vásiștha:NOM.PL } & \end{array}$

'O daughter of Heaven, the well-born Ușas, whom the Vasișțas make grow with prayers...'

(2) (RV 7.12.3b)

$\begin{array}{llll}\mathrm{t}_{\mathrm{u}} \text { vấm } & \text { vardh-a-nti } & \text { matíbhir } & \text { vásișthāḥ̆ } \\ \text { you:ACC } & \text { grow-PR-3PL.ACT } & \text { prayer:INS.PL } & \text { Vasișṭha:NOM.PL }\end{array}$

'The Vásiṣthas make you grow with prayers.'

(3) (RV 9.17.4c)

$\begin{array}{lll}\text { ukthaír } & \text { yajñéșu } & \text { vardh-a-te } \\ \text { hymn:INS.PL } & \text { sacrifice:LOC.PL } & \text { grow-PR-3SG.MID }\end{array}$

'He (sc. Soma) grows by hymns at the sacrifices.'

Likewise, the present form marjáyati 'wipes, purifies, adorns' is synonymous with the transitive present mấrști id.

\footnotetext{
${ }^{2}$ After the early Vedic period, that is in the language of Vedic prose, the -áya-causative vardháyati completely ousts the thematic root present várdhati (= class I present in the traditional Sanskrit grammar) in causative usages; see Gotō (1987: 292).
} 
This rule is only valid for the early Vedic period. From the middle Vedic period onwards, causatives can be derived from transitive verbs (see e.g. Hock 1981).

There are a number of important exceptions to Thieme's rule, which will be dealt with in this paper. I will argue that these exceptions can be accounted for by reformulating this rule in semantic terms, that is, essentially, in terms of Hopper and Thompson's approach to transitivity.

\subsection{Jamison's rule}

One such exception consists in the simple fact that there are some transitive verbs that can form causatives. Here belong verbs such as śru 'hear' (cf. śrnóti 'hears (tr.)' - śrẵváyati 'makes heard; makes hear'), pā 'drink' (cf. píbati 'drinks' - pāyáyati 'makes drink'). This group of verbs has been most explicitly described by Jamison (1983). Jamison points out the fact that these verbs can be constructed either with an accusative direct object or with an oblique (genitive, dative or locative) object, as in (4-5) (RV 8.36-37), accordingly labelling them intransitive/transitive (I/T) $:^{3}$

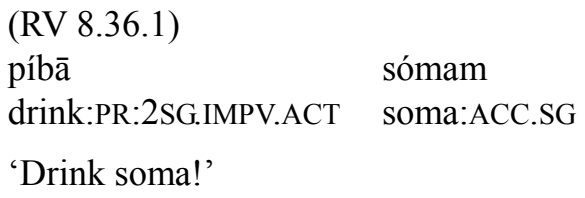

This class includes verbs of perception ('śru 'to hear', vid 'to know'), enjoying (jus 'to enjoy'), consuming ( $p \bar{a}$ 'to drink', bhaj 'to share in'), and some other minor semantic groups. Thus, both the syntax (DOM) and semantics of the I/T

\footnotetext{
${ }^{3}$ In typological literature, verbs that can be construed either with canonical direct objects (for instance, encoded with the accusative) or with non-canonical (non-accusative) direct objects are regarded as instantiating "differential object marking" (DOM for short); see, for instance, Bossong (1985), Aissen (1993), de Swart (2007) (to name but a few important publications). For a detailed discussion of this phenomenon in Vedic, see Dahl (2009).
} 
verbs distinguish them from canonical transitives. Accordingly, Thieme's rule can be modified as follows:

(R2) Both intransitive and intransitive/transitive (I/T) verbs can form morphological causatives.

Jamison's rule (R2) extends the range of verbs that can be causativized in early Vedic and, at the same time, provides a more adequate understanding of the syntactic classification of the Vedic verbs.

It turns out, however, that there remain some unexplained peculiarities in the behaviour of the Vedic morphological causatives - that is, some exceptions can still be found even to this revised rule (R2).

\subsection{Exceptions to Thieme/Jamison's rule}

First, there are a few verbs which form causatives in spite of the fact that they are transitives (i.e. neither intransitive nor I/T), cf. (sám) ìks 'look, see' (transitive) - (sám) ìksáyati 'makes see'; drós 'see' (transitive) - darśáyati ‘makes see, shows'.

Second, for some I/T verbs (in particular, for verbs of ruling, such as $r \bar{a} j$ 'rule' or $\bar{l} s$ 'possess; rule') causatives are unattested. Although the lack of corresponding causatives in texts may be accidental, of special interest are (semantic) verbal classes whose members never (or exceptionally) form causatives.

Finally - and most strikingly - some intransitive verbs do form long root syllable -áya-presents and/or reduplicated aorists that are, contrary to our expectations, employed non-causatively in some or most of their occurrences. These verbs deserve special attention and will be discussed at length in the following section.

4. Morphological causatives in non-causative usages

\section{1. krand 'roar, neigh'}

-áya-pres. krandaya ${ }^{t i}$ : $\quad$ intr.: $1 \times($ early $\mathrm{RV}) ; \quad$ tr.-caus.: $2 \times\left(\mathrm{RV}_{\mathrm{I}, \mathrm{X}}\right)$

red. aor. ácikrada- ${ }^{t}$ : intr.: $17 \times$; tr.-caus.: $3 \times$ 
Two of the three RVic attestations of the -áya-present krandaya- ${ }^{t i}$ appear in causative usages, attested in the late RV (books I and X), as in (6).

(6) (RV 10.102.5)

$\mathrm{n}_{\mathrm{i}} \mathrm{y}$ à-krand-aya-nn upayánta

down AUG-roar-PR.CAUS-3PL.IMPF.ACT approach:PR:PART.ACT:NOM.PL.M

enam [...] vrșabhám [...]

this:ACC.SG bull:ACC.SG

'The approaching ones have made him roar, the bull..."

The only occurrence in the early RV is non-causative:

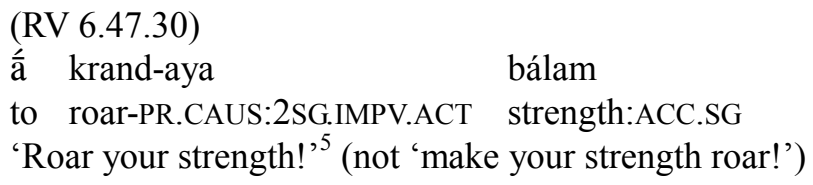

The reduplicated aorist ácikradat occurs twenty times in the RV and only rarely functions as causative. ${ }^{6}$ Normally, it is used intransitively, meaning 'has roared, has neighed', as in (8-10).

(8) (RV 9.67.4c)

$\begin{array}{lll}\text { hárir vấjam } & \text { acikradat } \\ \text { fallow } & \text { prize:ACC.SG } & \text { roar:AOR.CAUS:3SG.ACT }\end{array}$

'The fallow [horse] has neighed towards the race prize.'

(9) $\quad(\mathrm{RV} 1.58 .2 \mathrm{~d}=9.86 .9 \mathrm{a})$

divó ná sắnu

heaven:GEN.SG like top:NOM.SG

stanáyann acikradat

thunder:PR:PART.ACT:NOM.SG.M roar:AOR.CAUS:3SG.ACT

'Thundering like the top of the heaven, he has roared.'

\footnotetext{
${ }^{4}$ Geldner (1951: III, 318): "Die Herankommenden reizten ihn zum Brüllen, [...] den Stier..."

${ }^{5}$ Geldner (1951: II, 147): "Brülle uns Stärke zu" (not "laß die Stärke brüllen”). As Jamison (1983: 82) argues, following Thieme (1929: 28), the compound with the preverb á should be regarded as the denominative based on ākrandá- 'noise', meaning 'announce (thy strength)!' I see no good reason not to group this form with other non-causative usages of the verb krand.

${ }^{6}$ Cf. Renou (1961 [EVP IX]: 88): “acikradat [...] n'est qu'en partie caus.”.
} 
(10) (RV 4.24.8c)

ácikradad ví̛șaṇam pátn $\mathrm{i}_{\mathrm{y}}$ áchā

roar:AOR.CAUS:3SG.ACT bull:ACC.SG wife:NOM.SG to

'The wife has called the bull into the house.'

4.2.stan 'thunder'

-áya-pres. stanaya- ${ }^{t i}$ : intr.: $20 \times ; \quad$ tr.-caus.: unattested

The -áya-present stanáyati has a short root syllable before a nasal sonant. Thus, from the morphophonological point of view, this formation may instantiate either (i) a morphological causative built on the model of janáyati (with the root in the full grade, instead of the lengthened one), or (ii) a non-causative -áya-present, where an results from the zero grade of the root (i.e. stanaya- $<*^{*} \sin H-e$ eie-). In fact, causative usages are unattested for this present: stanáyati has the intransitive meaning 'thunders, roars', not 'makes thunder', in all of its occurrences (see Jamison 1983: 55), as in (11).

(11) (RV 1.79.2)
stanáyant $\mathrm{i}_{\mathrm{y}}$
abhrá
thunder:PR.CAUS:3PL.ACT cloud:NOM.PL
'The clouds thunder.' (Not 'make thunder'.)

\section{3.svan 'resound'}

-áya-pres. svanaya ${ }^{t i}{ }^{-}: \quad$ intr.: $1 \times ; \quad$ tr.-caus.: unattested

This root belongs to the same morphophonological type as stan, discussed above. Accordingly, svanaya ${ }^{t i}$ might represent either a morphological causative or a non-causative -áya-present (*svnH-eie-). The only attestation of svanaya ${ }^{t i}$ (3pl.act. svanayan RV 10.3.6) appears in an intransitive construction; see Jamison (1983: 55f).

\section{4. $n \bar{u}$ 'cry, praise'}

red. aor. ánūno- ${ }^{t}: \quad$ intr.: $2 \times$; $\quad$ tr.-caus.: - 
This root does not form -áya-presents. The reduplicated "causative" aorist occurs twice in the RV and is intransitive (non-causative) in both occurrences:

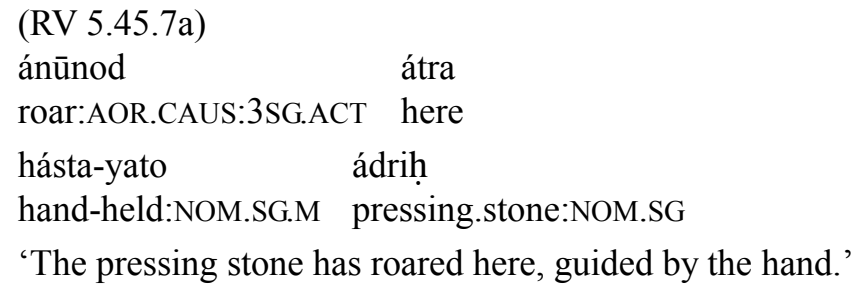

4.5. $m \bar{a}$ 'bellow, roar'

red. aor. ámime- ${ }^{t}: \quad$ intr.: $3 \times ; \quad$ tr.-caus.: unattested

The reduplicated aorist, attested three times in the RV, is employed intransitively, as in (14).

(14) (RV 1.164.9)

ámīmed vatsáh

bellow:AOR.CAUS:3SG.ACT calf:NOM.SG

'The calf has bellowed.'

4.6. sphürj 'roar, crackle, crash', non-alternating root

-áya-pres. sphūrjáya- ${ }^{t i}$ : intr.: $1 \times ; \quad$ tr.-caus.: unattested

This rare -áya-present is attested only once in the $\mathrm{RV}^{7}$ in a passage which poses some problems for translation, and is given in (15).

\footnotetext{
${ }^{7}$ Later, it appears once in the Aitareya-Brāhmana.
} 
(15) (RV 10.87.11cd)

tám arcísāan sphūrj-áya-ñ
he:ACC.SG flame:INS.SG crackle-PR.CAUS-PART.ACT:NOM.SG.M
jātavedah $\quad$ samaksám enam
Jātavedas:VOC.SG before.the.eyes he:ACC.SG
grnaté ní vrndhi
praise:PR:PART.ACT:DAT.SG.M down bend:PR:2SG.IMPV.ACT
'Throw him down, crackling with [your] flame, O Jātavedas, for the
praiser before [his] eyes.'

Geldner (1951: III, 278) interpreted this verb as intransitive: "Strecke ihn, o Jātavedas, knatternd mit deiner Flamme nieder für den Sänger vor dessen Augen!" ${ }^{\circ}$ By contrast, Jamison (1983: 120) saw here a causative, but her translation of the passage ("making him cry out by reason of thy flame...") seems forced and less plausible. The verb sphürj typically refers to sounds produced by the fire (crackling, booming, rumbling) rather than to those produced by human beings. See also Kölligan (2002: 145f.) for further evidence for an intransitive interpretation of this occurrence.

\section{7. vāś 'bellow, roar'}

$$
\begin{array}{lll}
\text {-áya-pres. } v \bar{a} \text { śaya }{ }^{t i}: & \text { intr.: unattested; } & \text { tr.-caus.: } 1 \times\left(\mathrm{RV}_{\mathrm{I}}\right) \\
\text { red. aor. ávīvaśa- }{ }^{t}: & \text { intr.: } 2 \times ; & \text { tr.-caus.: } 5 \times
\end{array}
$$

For this verb, an -áya-causative is attested once, in the late book I of the RV. The reduplicated aorist occurs seven times in the RV: five times in causative constructions and twice in intransitive usages (RV 9.21.7, 10.64.15), ${ }^{9}$ cf. (16).

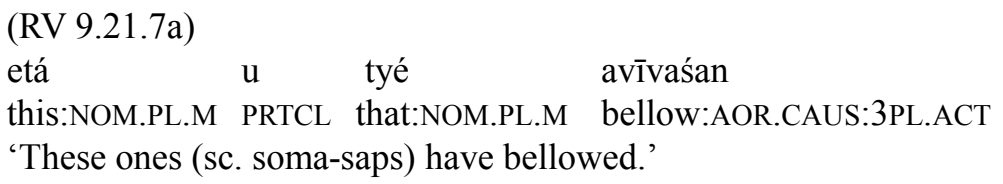

\footnotetext{
${ }^{8}$ Similarly Renou (1965 [EVP XIV]: 21; “Bruissant avec ta flame...”) and Elizarenkova (1999: 229; "Trešča plamenem...").

${ }^{9}$ See Jamison (1983: 166, fn. 127a). Cf. also Renou (1961 [EVP VIII]: 76) on the interpretation of avīvaśat in RV 9.32 .3 ("avivaśat, pseudo-transitif [...] Indécision sémantique de l'aoriste redoublé").
} 
Apparently, the six verbs discussed above share the following remarkable feature: all of them form morphological causatives, i.e. -áya-presents and/or reduplicated aorists, which are often, mainly or exclusively employed in noncausative usages. Most interestingly, these verbs also have a semantic feature in common: they denote different kinds of sounds produced by human beings or, more often, by animals, deities, natural forces, such as thunder or fire. Accordingly, it is advisable to take a closer look at other verbs of sound. It turns out that nine other verbs of sound do not form causatives in early Vedic, in spite of their intransitivity. These include:

1. krakṣ 'roar': causatives are unattested;

2. kruś 'cry (at), shout (at)': causatives are unattested. The post-Vedic agent noun a akrośayitar- derived from the causative stem -krośay(a)occurs in a non-causative construction:

(17) (Vișnu-Smrti 5.23)

ā-kroś-ay-itā ca vi-jihvah

to-shout-PR.CAUS-AG.NOUN:NOM.SG and without-tongue:NOM.SG.M ' $\ldots$ and the one who shouts [at his superior in caste] [should be] deprived of tongue'.

3. jakṣ 'laugh': causatives are unattested;

4. nad 'roar': causatives first appear in Epic Sanskrit (see Oberlies 2003: 456)

5. pruth 'pant, neigh, snort': causatives are unattested. The absolutive prothya (derived from the causative stem proth(aya)-), attested at Āśvalāyana-Śrauta-Sūtra 6.13 .10 , is employed in a non-causative construction:

(18) (Āśvalāyana-Śrauta-Sūtra 6.13.10) proth-ya prathamena pra-șțīvanti snort:PR.CAUS-CONV first:INS.SG.M/N forward-spit:PR:3SG.ACT '.. after having gargled with the first [portion of water] they spit [it] out'.

6. $r \bar{a}$ 'bark': causatives are unattested; 
7. $r u$ 'cry, roar': caus. rāvayati from Śrauta-Sūtras ${ }^{10}$ onwards;

8. siñ j 'tinkle, rattle, bellow': causatives are unattested;

9. heș 'neigh': causatives are unattested.

For two other verbs of sound, causatives are only but scarcely attested in Early Vedic:

10. ví-lap 'cry' (caus. vi lāpayati AV 1.7.2 =6) (see Jamison 1983: 117);

11. śvas 'hiss, snort' (caus. úpa śvāsaya RV 6.47.29) (see Jamison 1983: 119).

In summary, all verbs of sound share the following features: (i) causatives to these verbs are unattested or rare and/or late, in spite of their intransitivity; and (ii) in the cases where morphological causatives, i.e. -áya-presents and/or reduplicated aorists, are attested, they can be employed in non-causatives (intransitive) constructions.

In my view, this remarkable peculiarity of verbs of sound can be accounted for in terms of the semantic approach to transitivity as outlined by Hopper and Thompson (1980).

5. Reformulating Thieme's rule: a semantically oriented approach

It seems that Thieme's rule enables us to adequately capture the main constraints on the causative derivation if we reformulate the notion of transitivity in semantic terms, instead of using a purely syntactic (and traditional) definition based on the absence/presence of an accusative direct object.

As already mentioned, there are several semantic parameters that correlate with high/low degree of transitivity. Elsewhere (Kulikov 1999) I have argued that some irregularities in transitivity and causativity of certain Vedic forms can be explained in terms of this semantic approach to transitivity, substantiated by Hopper and Thompson (1980). In particular, this approach is capable to account for the polysemy of causative morphemes and non-causative use of causative morphology: next to expressing causative meaning in the strict sense

${ }^{10}$ Āśvalāyana-Śrauta-Sūtra 2.18.12. 
of the term, causative affixes may, in some languages and/or with some verbs, have other functions correlated with the higher degree of transitivity. In this section I will show that this approach readily explains the non-causative usages of the Vedic causatives mentioned and discussed above.

One of the most important semantic parameters that correlates with high transitivity is the agentivity of subject, or, in Hopper and Thompson's terms, the degree of directed physical activity in the event to which the verb refers. This means that the absence or low degree of agentivity (or volitionality) of the actor, or subject, correlates with intransitivity or at least a low degree of transitivity in the clause. By contrast, a high degree of agentivity exhibited by the actor correlates with a high degree of transitivity.

For instance, in Estonian, the direct object may surface in the genitive or in the partitive case. The former covers most of the usual functions of the accusative, while the partitive appears if the degree of the agentivity of the subject is low. ${ }^{11}$ Example (19) illustrates this correlation between transitivity and agentivity.

(19a) Ta tundis seda naist.

he knew this woman:PART

'He knew this woman.'
Ta tundis selle naise
ära.
he knew this woman:GEN
away
'He recognized this woman.'

In (19b) the verb tundis, which normally takes a partitive object, is interpreted as suggesting the more active participation of the subject, and therefore the object receives the genitive marking instead of the partitive one.

Different encoding (case-marking or type of verbal agreement) of the subject of an intransitive verb, depending on its agentivity (agentive/inagentive) - same as the encoding of the subject of a transitive verb vs. the encoding of the direct object of a transitive, respectively - represents a constituent feature of languages with the active type of alignment. A few typical examples

\footnotetext{
${ }^{11}$ Another parameter that is responsible for the case-marking of the direct object in many Finno-Ugric languages is the aspectual characteristics of the verb. Thus, in Finnish the perfective aspect, arguably correlating with a higher degree of transitivity, selects the accusative case of the direct object, whilst the imperfective aspect, which implies a lower degree of transitivity, selects the partitive case (Hopper and Thompson 1980: 271).
} 
can be taken from Choctaw (an Amerindian language of the Muskogean family; cf. (20-23), quoted from Kittilä 2002: 81), where the 1st person intransitive subject can trigger the same agreement marker in the verb (-sa-) as the object of a transitive verb (cf. (21)) in cases where the degree of control the subject exercises over the activity is low, as in (22). By contrast, the 1st person marker -li- is used for agentive subjects, as in (20) and (23).

(20) chi-bashli-li-tok

2.ACC-CUT-1.NOM-PAST

'I cut you.'

(21) is-sa-ssa-tok

2.NOM-1.ACC-HIT-PAST

'You hit me.'

(22) sa-ttola-tok

1.ACC-FALL-PAST

'I fell.'

ittola-li-tok

fall-1.NOM-PAST

'I fell (on purpose).'

Similar phenomena can be found in other active languages, also known as languages with "split intransitivity", such as Bats(bi) (East Caucasian; see Holisky 1987) or Guaraní (Tupi-Guarani, South America). ${ }^{12}$ To put it more generally, among the clauses traditionally qualified as "intransitive", we are able to distinguish between those which are "more intransitive" (= prototypical intransitive) and those which are "less intransitive" (sharing some features with transitive clauses, cf. (23)). Likewise, "transitive" constructions can be ranked, in accordance with their degree of transitivity, as "more transitive" (= prototypical transitive) vs. "less intransitive". In general, the degree of transitivity is higher if the subject is more Agent-like.

\footnotetext{
${ }^{12}$ There are also some reasons to assume that the active type can be reconstructed for early Proto-Indo-European. According to this hypothesis, going back a far as Uhlenbeck (1901) (and later advocated by Pedersen 1907; Lehmann 1958; Ivanov and Gamkrelidze 1995: 238ff.; Kortlandt 2010; among others), active arguments of intransitive verbs were encoded with the suffix *- $(o) s$, while inactive arguments took the "inactive" suffix *-m. Later these morphemes were reinterpreted as the nominative ending of masculine nouns and the nominative-accusative ending of neuter nouns, respectively.
} 
Prototypical (in)transitivity is influenced by both syntactic and semantic parameters. ${ }^{13}$ A verb can be treated as prototypically transitive if it is both syntactically and semantically transitive, that is, (i) it is constructed with an accusative direct object, and (ii) its subject is a prototypical Agent, exercising control over the activity (cf. such verbs as carry, wipe, destroy, build, etc.). On the other hand, a verb can be characterized as prototypically intransitive if it is both syntactically and semantically intransitive, i.e. (i) it is not constructed with an accusative direct object, and (ii) its subject is a prototypical Patient which does not exercise control over the activity and typically undergoes some physical changes (cf. verbs such as die, (become) dry, fall, etc.).

The non-homogeneous character of the class of intransitives has been the subject of research in the studies of the last decades dealing with the Unaccusativity Hypothesis and split intransitivity; see e.g. Merlan 1985; Van Valin 1990; Levin and Rappaport Hovav 1995. In particular, Shibatani (2001) points out that non-agentive (inactive) intransitives are more likely to be able to causativize than the agentive ones ${ }^{14}$ (see also Shibatani and Pardeshi 2001).

Prototypical transitives and prototypical intransitivesare the two extremes, the two poles on the Transitivity Scale, along which all verbs can arguably be arranged. ${ }^{15}$ Obviously, the verbs for which syntactic and semantic (in)transitivity do not match, that is, non-prototypical transitives and intransitives, should be located between these two poles. These intermediary classes include, in particular:

(i) Syntactically intransitive verbs (i.e. verbs constructed without an accusative direct object) which have an agentive subject. Here must belong, among others, verbs of (controllable) sound, such as cry or roar.

\footnotetext{
${ }^{13}$ This claim is by no means a novelty; it was substantiated in the above-mentioned seminal paper Hopper and Thompson (1980) and further elaborated in numerous publications, such as DeLancey (1987), Testelec (1998) and Næss (2007) (to name but a few). For a detailed discussion of several aspects of the contribution of both syntactic and semantic features to the degree of transitivity (in particular, in ancient Indo-European languages), see also my earlier paper, Kulikov (1999).

14 “As it turns out, intransitives are not uniform in their response to morphological causativization in that inactive intransitives (roughly corresponding to Perlmutter's unaccusative predicates) are more susceptible to causative conversion than active intransitives (roughly corresponding to Perlmutter's unergative predicates)" (Shibatani 2001: 5).

${ }^{15}$ For a detailed discussion of the notion of Transitivity Scale, see, in particular, Lazard (1994: 167f., $231 \mathrm{ff}$., 247ff.) and Premper (2001: 490f).
} 
(ii) Syntactically transitive verbs of perception and enjoying (see, hear, enjoy, etc.) which are constructed with accusative direct objects in many languages (in particular, in Vedic). Since their subjects typically refer to an Experiencer rather than to an Agent, they are lacking an important transitivity feature.

In other words, the subjects of the verbs that refer to controllable, volitionally and purposefully produced sounds show a rather high degree of agentivity. Accordingly, such subjects are arguably closer to the prototypical Agent than, for instance, the experiential subjects of the verbs of perception, which denote non-controllable (or less controllable) events. From the point of view of the semantic type of the subject, such verbs must be further from the (semantically defined) transitive prototype than such syntactically intransitive but more agentive verbs as cry or roar.

Yet another group of transitive verbs that, in many languages, exhibit syntactic peculiarities that deviate from the transitive prototype includes ingestive verbs (verbs of consuming), such as drink or eat. First, their objects (i.e. objects of consumption) may show non-canonical (in particular, nonaccusative) object marking. This is, in particular, due to the fact that partitive objects are quite common with ingestive verbs, which accounts for their non-accusative (partitive) case-marking in several languages - for instance, in a number of Slavic languages. Second, they often share some features with intransitives. In particular, they may causativize in languages where normally only intransitives (but not transitives) causativize. As in the case with other non-canonical transitives, their deviation from the transitive prototype seems to lie in the semantics of their main arguments. Although their Agents are more agentive than those of the verbs of perception and enjoying, they also appear to exhibit some features which distinguish them from canonical Agents. Specifically, as Shibatani (2001: 6) argues, the subjects of such verbs "are both agentive and patientive - they both act and get affected."

All in all, the classes of verbs discussed above fit into Shibatani's (2001: 5f.) semantic classification of verbs which is relevant for a description of causativization, particularly in the languages where only some sub-sets of verbs allow for (some particular type of) causativization. As Shibatani argues, while verbs of perception, enjoying and consuming often group with intransitives, active (agentive) intransitives (approximately corresponding to the

\footnotetext{
${ }^{16}$ This also holds for some "middle" transitive verbs, such as learn or put on (clothes); see Shibatani (2001).
} 
unergative class in studies on the Unaccusativity Hypothesis and split intransitivity) display some syntactic features of transitives.

The verbs belonging to these intermediary groups can be referred to as quasi-intransitives and quasi-transitives. Obviously, they should be placed in the middle of the Transitivity Scale, as shown in (24):

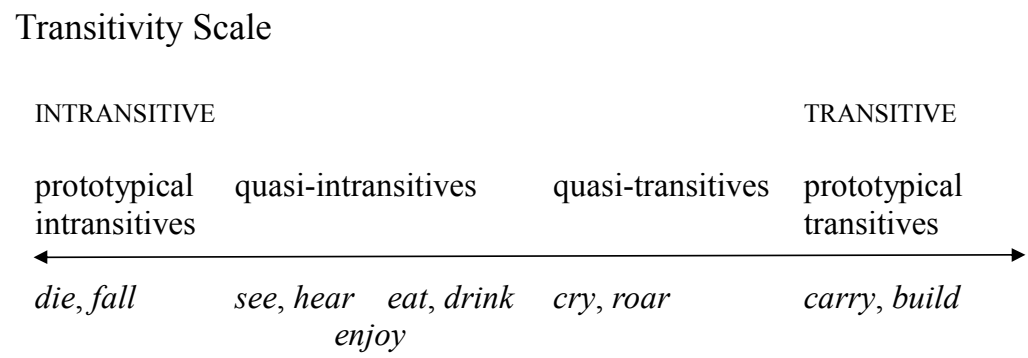

In terms of the Transitivity Scale (24), we can reformulate Thieme's rule on constraints on the causative derivation in early Vedic as follows:

(R3a) The causative derivation is possible for (i) verbs which are prototypically intransitive, or (ii) verbs which are syntactically transitive (or I/T), but semantically intransitive (quasi-intransitive) verbs. These include, in particular, verbs of perception, enjoying and consuming, which are constructed with non-canonical (in particular, experiential) subjects, deviating from agentive prototypes.

(R3b) The causative derivation is impossible for (i) verbs which are prototypically transitive, or (ii) verbs which are syntactically intransitive, but semantically transitive, i.e. verbs which have an agentive subject (in particular, verbs of controllable sound).

\section{The Vedic verbal classes on the Transitivity Scale}

In terms of this modified rule, based on the semantic approach to transitivity, a number of exceptions to Thieme's rule can be accounted for. The verbal classes which do not meet this rule (listed in Sections 3.3 and 4) can be arranged according to the degree of transitivity as follows: 


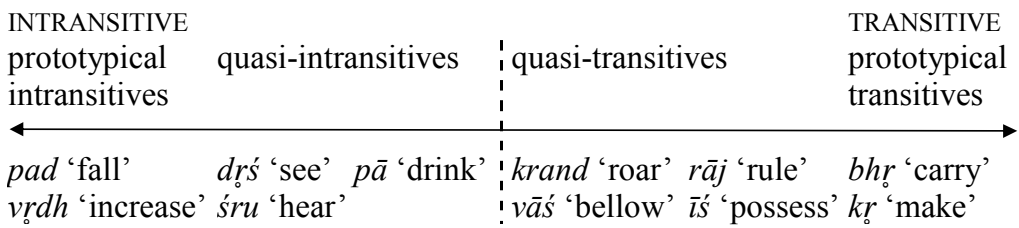

Next to the verbs of sound, there is another small group of semantically transitive (but syntactically intransitive-transitive, I/T) verbs, viz. verbs of ruling. They can be constructed either with an accusative or with a non-accusative (genitive) object, thus being I/T in Jamison's terms. In spite of this syntactic feature, they do not form causatives, contrary to Jamison's rule, thus being different from such $\mathrm{I} / \mathrm{T}$ verbs as verbs of perception or consuming ( $p \bar{a}$ 'drink', śru 'hear', etc.). This must be due to the fact that the subjects of these verbs are more agentive than those of prototypical intransitives, which accounts for their semantic transitivity, even in spite of their syntactic intransitivity.

In terms of this semantically-based approach to transitivity, we can also explain why such syntactically transitive verbs as $\bar{\imath} k s$ 'look' or $d r s$ ' 'see' form -áya-causatives. Most likely, semantic criteria (the low agentivity of the subject) are, in this case, more relevant than syntactic features (syntactic transitivity) for determining the position of the verb in question on the Transitivity Scale. Although $\bar{\imath} k s$ and $d r r^{\prime}$ can only be constructed with accusatives and not with oblique objects, for semantic reasons they can be grouped with other verbs of perception, i.e. with the I/T verbs such as śru 'hear', etc.

Next to the (semantically intransitive) verbs of perception such as $\bar{k} k s$ 'look', $d r s^{\prime}$ 'see' and śru 'hear', there is yet another verb, spas' 'look, watch; spy out', which is worthy of special discussion. At first glance, it belongs to the same semantic class as the above-listed verbs of perception. Accordingly, one might expect that the regular causative derivation is possible for this verb. However, the -áya-present attested but once in the RV occurs in the noncausative usage, meaning 'spy out', not 'make spy out, cause to spy out':

$$
\text { (RV 1.176.3) }
$$

$\begin{array}{lll}\text { spāś-áya-sva } & \text { yó } & \text { asma-dhrúk } \\ \text { watch-PR.CAUS-2SG.IMPV.MID } & \text { who:NOM.SG.M } & \text { us-deceptive:NOM.SG.M } \\ \text { 'Watch the one who is deceptive towards us. } & \text { 17 }\end{array}$

${ }^{17}$ Cf. Geldner (1951: I, 255): "mach du den ausfindig, der uns nachstellt". 
Jamison's (1983: 167) translation of this form as causative ("(O Indra,) do thou cause (the one) who is our deceiver to be spied out") seems somewhat forced. The reformulation of the meaning 'watch' on the model of such causative verbs as darśáyati ('see' - 'make seen') does not seem convincing, since, in the case of spaś, the intransitive member of the opposition (*'be spied out') is unattested.

In my opinion, this morphological causative can readily be accounted for in semantic terms, cf. rule (R3b). The exceptional syntactic characteristics of this verb may be due to its semantic features. In fact, spaś differs from other verbs of perception, such as $\bar{l} k s$ or $d r s^{\prime}$ 'see, look'. It is constructed with the subject (a watcher or a spy) which retains control over the activity, so that, semantically, it instantiates an Agent rather than an Experiencer. This means that spaś is closer to canonical transitive verbs rather than to the verbs of perception of the type $i k s$ or $d r \dot{s}$. Accordingly, one might expect that the "morphological causative" (i.e. the -áya-present) of spaś can be employed in non-causative usages of the same type as attested for other formations derived from this root, such as perfect paspase 'watches, has watched, has spied out' (see Kümmel 2000: 586f.).

\section{Theoretical conclusions and typological implications}

In Early Vedic, the exact location of the borderline between (semantic) intransitives, for which a causative derivation was possible, and (semantic) transitives, which could not form causatives, can readily be determined in terms of the Transitivity Scale. It seems that this border is situated somewhere to the left of verbs of sound. Later on, it moved to the right, and eventually, by the middle Vedic period (i.e. in the language of the Vedic prose), the causative derivation had become possible for transitives.

Apparently, the notion of transitivity should be determined separately for different languages. If we determine transitivity as a set of parameters, some verbs can display only a subset of transitivity or (conversely) intransitivity features. Thus, instead of the traditional binary classification (intransitive vs. transitive verbs), in some cases a more complex gradual classification (e.g., prototypically intransitive - quasi-intransitive - quasi-transitive - prototypically transitive) appears to be more adequate. The number of relevant classes should be determined separately for individual languages, on the basis of the relevant syntactic phenomena, such as the causative derivation. Moreover, the 
scope of transitivity can change within a particular language during the course of its history.

\section{REFERENCES}

Aissen, J. 2003. "Differential object marking. Iconicity vs. economy". Natural Language and Linguistic Theory 21. 435-483.

Bossong, G. 1985. Empirische Universalienforschung. Differentielle Objektmarkierung in den neuiranischen Sprachen. Tübingen: Narr.

Dahl, E. 2009. "Some semantic and pragmatic aspects of object alternation in Early Vedic". In: Barđdal, J. and S.L. Chelliah (eds.), The role of semantic, pragmatic, and discourse factors in the development of case. (Studies in Language Companion Series 108). Amsterdam: Benjamins. 23-55.

DeLancey, S. 1987. "Transitivity in grammar and cognition”. In: Tomlin, R.S. (ed.), Coherence and grounding in discourse: Outcome of a Symposium, Eugene, Oregon, June 1984. (Typological Studies in Language 11). Amsterdam: Benjamins. 53-68.

Elizarenkova, T.J. 1989-1999. Rigveda. Mandaly I-IV (1989); Mandaly V-VIII (1995); Mandaly $I X-X$ (1999). Perevod i kommentarii T.J. Elizarenkovoj [Rogveda. Maṇalalas I-IV; Maṇdalas V-VIII; Mandalas IX-X. Translation and commentaries by T.J. Elizarenkova]. Moskva: Nauka.

Geldner, K.F. 1951. Der Rig-veda aus dem Sanskrit ins Deutsche übersetzt und mit einem laufenden Kommentar versehen von K.F. Geldner. (Vols. 1-3.) (Harvard Oriental Series 33-35). Cambridge, MA: Harvard University Press.

Gotō, T. 1987. Die "I. Präsensklasse" im Vedischen: Untersuchung der vollstufigen thematischen Wurzelpräsentia. Wien: Verlag der Österreichischen Akademie der Wissenschaften. (2., überarbeitete und ergänzte Aufl. 1996.)

Hock, H.H. 1981. "Sanskrit causative syntax: A diachronic study". Studies in the linguistic sciences 11(2). 9-33.

Holisky, D.A. 1987. "The case of the intransitive subject in Tsova-Tush (Batsbi)". Lingua 71. 103-132.

Hopper, P.J. and S.A. Thompson. 1980. "Transitivity in grammar and discourse". Language 56(2). 251-299.

Ivanov, V.V. and T.V. Gamkrelidze. 1995. Indo-European and the Indo-Europeans. A reconstruction and historical analysis of a proto-language and proto-culture. (Parts I-II). Berlin: de Gruyter.

Jamison, S.W. 1983. Function and form in the -áya-formations of the Rig Veda and Atharva Veda. (KZ; Ergänzungsheft 31). Göttingen: Vandenhoeck und Ruprecht.

Kittilä, S. 2002. Transitivity: Towards a comprehensive typology. (University of Turku. Publications in General Linguistics 5). Turku: University of Turku.

Kölligan, D. 2002. "Zur Funktion schwundstufiger -éie-Präsentia im Indogermanischen". In: Hettrich, H. (ed.), Indogermanische Syntax - Fragen und Perspektiven. Wiesbaden: Reichert. 137-156. 
Kortlandt, F.F.H. 2010. “An outline of Proto-Indo-European”. In: Kortlandt, F.F.H., Studies in Germanic, Indo-European and Indo-Uralic. (Leiden Studies in Indo-European 17). Amsterdam: Rodopi. 37-45.

Kulikov, L. 1999. "Split causativity: Remarks on correlations between transitivity, aspect, and tense". In: Abraham, W. and L. Kulikov (eds.), Tense-aspect, transitivity and causativity. Essays in honour of Vladimir Nedjalkov. (Studies in Language Companion Series 50). Amsterdam: Benjamins. 21-42.

Kulikov, L. 2005. "Reduplication in the Vedic verb: Indo-European inheritance, analogy and iconicity". In: Hurch, B. (ed.), Studies on reduplication. (Empirical Approaches to Language Typology 28). Berlin: de Gruyter. 431-454.

Kulikov, L. 2008. "The Vedic type patáyati revisited: Semantic oppositions, paradigmatic relationships and historical connections". In: Lubotsky, A., J. Schaeken and J. Wiedenhof (eds.), Evidence and counter-evidence: Essays in honour of Frederik Kortlandt. (Vol. I. Balto-Slavic and Indo-European Linguistics.) (Studies in Slavic and General Linguistics 32). Amsterdam: Rodopi. 323-342.

Kulikov, L. 2012. "Vedic preverbs as markers of valency-changing derivations: Transitivity and objecthood in Indo-European (Evidence from Old Indo-Aryan)". Studies in Language 36(4). 721-746.

Kümmel, M. 2000. Das Perfekt im Indoiranischen. Wiesbaden: Reichert.

Lazard, G. 1994. L'actance. Paris: Presses Universitaires de France.

Lehmann, W.P. 1958. "On earlier stages of the Indo-European nominal inflection". Language 34(2). 179-202.

Leumann, M. 1962. "Der altindische kausative Aorist ajījanat”. In: Bender, E. (ed.), Indological studies in honor of $W$. Norman Brown. New Haven: American Oriental Society. 152-159.

Levin, B and M. Rappaport Hovav 1995. Unaccusativity: At the syntax-lexical semantics interface. (Linguistic Inquiry Monograph 26). Cambridge, MA: The MIT Press.

LIV [= Lexikon der indogermanischen Verben]. 2001. Lexikon der indogermanischen Verben. Die Wurzeln und ihre Primärstammbildungen. Unter Leitung von Helmut Rix und der Mitarbeit vieler anderer bearbeitet von M. Kümmel, T. Zehnder, R. Lipp, B. Schirmer. 2., erweiterte und verbesserte Auflage. (1. Auflage: 1998) Wiesbaden: Reichert.

Lubotsky, A. 1989. “The Vedic -áya-formations”. Indo-Iranian Journal 32. 89-113.

Lubotsky, A. 1997. Review of: Volkart 1994. Kratylos 42. 55-59.

Macdonell, A.A. 1910. Vedic grammar. Strassburg: Trübner.

Merlan, F. 1985. "Split intransitivity: functional oppositions in intransitive inflection". In: Nichols, J. and A.W. Woodbury (eds.), Grammar inside and outside the clause: Some approaches to theory from the field. Cambridge: Cambridge University Press. 324-362.

Næss, Å. 2007. Prototypical transitivity. (Typological Studies in Language 72). Amsterdam: Benjamins.

Oberlies, T. 2003. A grammar of Epic Sanskrit. (Indian Philology and South Asian Studies 5). Berlin - New York: de Gruyter.

Pedersen, H. 1907. "Neues und nachträgliches”. Zeitschrift für vergleichende Sprachforschung 40. 129-217. 
Premper, W. 2001. "Universals of the linguistic representation of situations ("participation')". In: Haspelmath, M. et al. (eds.), Language typology and language universals. An international handbook. (Vol. 1.) Berlin: de Gruyter. 477-495.

Renou, L. 1952. Grammaire de la langue védique. Lyon, Paris: IAC.

Renou, L. 1955-1969. Études védiques et pāninéennes. [EVP] (Vols. I-XVII.) Paris: Boccard.

Shibatani, M. 2001. "Introduction: Some basic issues in the grammar of causation". In: Shibatani, M. (ed.), The grammar of causation and interpersonal manipulation. (Typological Studies in Language 28.) Amsterdam: Benjamins. 1-22.

Shibatani, M. and P. Pardeshi. 2001. "The causative continuum". In: Shibatani, M. (ed.), The grammar of causation and interpersonal manipulation. (Typological Studies in Language 28). Amsterdam: Benjamins. 85-126.

Swart, P. de. 2007. Cross-linguistic variation in object marking. (PhD dissertation, University of Nijmegen.)

Testelec, Y. 1998. "On two parameters of transitivity". In: Kulikov, L. and H. Vater (eds.), Typology of verbal categories. Papers presented to Vladimir Nedjalkov on the occasion of his 70th birthday. Tübingen: Niemeyer. 29-45.

Thieme, P. 1929. Das Plusquamperfektum im Veda. (KZ; Ergänzungsheft 7). Göttingen: Vandenhoeck \& Ruprecht.

Tsunoda, T. 1981. "Split case-marking patterns in verb-types and tense/aspect/mood". Linguistics 19(5-6). 389-438.

Tsunoda, T. 1985. "Remarks on transitivity". Journal of Linguistics 21(2). 385-396.

Uhlenbeck, C.C. 1901. "Agens und Patiens im Kasussystem der indogermanischen Sprachen". Indogermanische Forschungen 12. 170-171.

Van Valin, R.D. 1990. "Semantic parameters of split intransitivity". Language 66(2). 221-260.

Volkart, M. 1994. Zu Brugmanns Gesetz im Altindischen. Bern: Universität Bern.

\section{Address correspondence to:}

Leonid Kulikov

Universiteit Gent

Faculteit Letteren en Wijsbegeerte, Vakgroep Taalkunde

Muinkkaai 42

9000 Ghent

Belgium

Leonid.Kulikov@UGent.be 